Article

\title{
Biodegradation of Allethrin by a Novel Fungus Fusarium proliferatum Strain CF2, Isolated from Contaminated Soils
}

\author{
Pankaj Bhatt ${ }^{1,2} \oplus$, Wenping Zhang ${ }^{1,2}$, Ziqiu Lin ${ }^{1,2}$, Shimei Pang ${ }^{1,2}$, Yaohua Huang ${ }^{1,2} \odot$ and \\ Shaohua Chen $1,2, * \mathbb{B}$ \\ 1 State Key Laboratory for Conservation and Utilization of Subtropical Agro-bioresources, Guangdong \\ Province Key Laboratory of Microbial Signals and Disease Control, Integrative Microbiology Research \\ Centre, South China Agricultural University, Guangzhou 510642, China; \\ pankajbhatt.bhatt472@gmail.com (P.B.); 20191047008@stu.scau.edu.cn (W.Z.); \\ 20192047010@stu.scau.edu.cn (Z.L.); 20192047012@stu.scau.edu.cn (S.P.); 20183138021@stu.scau.edu.cn (Y.H.) \\ 2 Guangdong Laboratory for Lingnan Modern Agriculture, Guangzhou 510642, China \\ * Correspondence: shchen@scau.edu.cn; Tel.: +86-20-8528-8229; Fax: +86-20-8528-0292
}

Received: 24 March 2020; Accepted: 17 April 2020; Published: 20 April 2020

\begin{abstract}
Continuous use of allethrin has resulted in heavy environmental contamination and has raised public concern about its impact on human health, yet little is known about the kinetics and microbial degradation of this pesticide. This study reported the degradation kinetics in a novel fungal strain, Fusarium proliferatum CF2, isolated from contaminated agricultural fields. Strain CF2 utilized $50 \mathrm{mg} \cdot \mathrm{L}^{-1}$ of allethrin as the sole carbon source for growth in minimal salt medium and tolerated high concentrations of allethrin of up to $1000 \mathrm{mg} \cdot \mathrm{L}^{-1}$. The optimum degradation conditions for strain CF2 were determined to be a temperature of $26^{\circ} \mathrm{C}$ and $\mathrm{pH} 6.0$ using response surface methodology. Under optimum conditions, strain CF2 completely degraded allethrin within 144 hours. The degradation kinetics of allethrin followed first order reaction kinetics. Kinetics analysis showed that its half-life was substantially reduced by 507.1 hours, as compared to the uninoculated control. This study provides new insights into the microbial degradation of allethrin with fungal F. proliferatum CF2.
\end{abstract}

Keywords: allethrin; Fusarium proliferatum; biodegradation; metabolic pathway; kinetics

\section{Introduction}

Allethrin (2-methyl-4-oxo-3-(2-propanyl)-2-cyclopenten-lyl-2-2-dimethyl-3-(2-methyl-1-propenyl cyclopropane)-carboxylate) is a synthetic pyrethroid compound that is widely used to control flies and mosquitoes in the home, crawling and flying insects on animal farms, and fleas and ticks on dogs and cats [1]. Allethrin was the first synthetic pyrethroid synthesized in the USA by Milton S. Schechter in 1949. Like all pyrethroids, it acts as an axonic poison that binds and stops the function of sodium ion channels, resulting in hyperactivity of the nervous system and, finally, paralysis and death of insects [2]. Allethrin has a broad application in mosquito-borne diseases and agricultural pest control [3]. However, the widespread application of allethrin causes heavy environmental contamination and also affects human health [4]. The large-scale use of domestic pesticides as mosquito repellents is greatly increasing concerns about its toxicity. Applied pesticides reach natural targets such as air, water, and soil. Pyrethroids constitute about $25 \%$ of the total global insecticide market, indicating its importance and application value [5]. On the basis of their chemical structure and mechanism, pyrethroids are divided into two broad categories, namely, Type I and Type II. Allethrin is a Type I pyrethroid because it lacks the $\alpha$-cyano group [6,7]. 
Allethrin is released from different households and agricultural operations and persists in the environment for a long time. Mammals' degradation of allethrin leads to the formation of free radicals that cause DNA damage and damage to the integrity of the membrane, which causes cell death $[8,9]$. Allethrin-induced reactive species create oxidative cell damage in human erythrocyte cells [10]. Neurotoxicity in the presence of allethrin has been reported in rodents [10]; it causes genotoxicity in human peripheral blood lymphocytes, as well as in Swiss albino mice [11,12]. In humans, allethrin causes toxicity in corneal epithelial cells through mitochondrial-mediated apoptosis [13], and the biochemical profiles of plasma cells in humans are altered by allethrin [14].

Due to the large-scale application of pyrethroids in the agricultural system, they can persist for a long time on the basis of biotic and abiotic factors [15]. These chemicals reach the bottom layers of the soil and thus might contaminate groundwater bodies. Finally, the concentration increases in the ecosystem via various direct and indirect routes through the biomagnification process [16]. Biodegradation is an eco-friendly approach to remove pyrethroid residues from the environment [17-19], and bacterial-based biodegradation of pesticides is emphasized more compared to fungal strains [20]. However, several reports have identified the potential fungal genera for pyrethroid degradation. These microbial strains have the potential to utilize pyrethroids as a sole source of carbon and nitrogen, such as Aspergillus, Candida, Trichoderma, Eurotium, and Cunninghamella [21-28]. Fungi may produce other intracellular and extracellular enzymes that play an important role in pyrethroid degradation. For the biodegradation of pesticides, fungi are considered to be the better potential candidates compared to bacteria [20]. Naturally, white rot fungi have the robustness for degradation of recalcitrant chemicals in the environment $[29,30]$. Pyrethroids were firstly degraded by cleavage of the ester bond, due to the presence of an enzyme known as pyrethroid hydrolase [31,32]. Among pyrethroids, allethrin has been given less emphasis in degradation research-only the allethrin-degrading bacteria Acidomonas sp. and Sphingomonas trueperi have been identified previously [2,33,34].

To date, little is known about allethrin biodegradation by fungi associated with metabolic behaviors and kinetics. Therefore, the aim of the study was: (1) to isolate and identify allethrin-degrading fungi from contaminated agricultural soils; (2) to investigate the degradation kinetics of allethrin in minimal salt medium; (3) to optimize the degradation conditions with isolated fungi; and (4) to characterize the metabolic pathway of allethrin. The results of this study will help to explore the role of fungi in the degradation of allethrin and similar pesticides.

\section{Materials and Methods}

\subsection{Chemicals and Media}

Technical grade allethrin and other synthetic pyrethroids used for the present experiment were purchased from Sigma-Aldrich, St. Louis, MO, USA. The acetonitrile used for the chromatographic analysis was obtained from Sigma-Aldrich, USA. Allethrin was dissolved in acetone at a stock concentration of $10 \mathrm{~g} \cdot \mathrm{L}^{-1}$ and stored in a dark bottle in a refrigerator at $4{ }^{\circ} \mathrm{C}$. This stock was used for the degradation analysis of allethrin. The mineral salt medium (MSM) containing $2 \mathrm{~g}\left(\mathrm{NH}_{4}\right)_{2} \mathrm{SO}_{4}, 0.2 \mathrm{~g}$ $\mathrm{MgSO}_{4} \cdot 7 \mathrm{H}_{2} \mathrm{O}, 0.01 \mathrm{~g} \mathrm{CaCl}_{2} \cdot 2 \mathrm{H}_{2} \mathrm{O}, 0.001 \mathrm{~g} \mathrm{FeSO} \cdot \cdot 7 \mathrm{H}_{2} \mathrm{O}, 1.5 \mathrm{~g} \mathrm{Na} 2 \mathrm{HPO}_{4} \cdot 12 \mathrm{H}_{2} \mathrm{O}$, and $1.5 \mathrm{~g} \mathrm{KH} \mathrm{PO}_{4}$ per liter was used for the biodegradation assays in the study. Czapek-Dox medium (CDM) containing (in grams per liter) sucrose, $30 ; \mathrm{NaNO}_{3}, 2 ; \mathrm{KCl}, 0.5 ; \mathrm{MgSO}_{4}, 0.5 ; \mathrm{K}_{2} \mathrm{HPO}_{4}, 1 ; \mathrm{Fe}_{2}\left(\mathrm{SO}_{4}\right)_{3}, 0.01$; and peptone, 0.5 , was used for the cultivation of fungal strains in the laboratory. Both media were autoclaved at $121^{\circ} \mathrm{C}$ for $20 \mathrm{~min}$ before fungal strain inoculation.

\subsection{Enrichment and Isolation of Allethrin-Degrading Fungi}

Soil samples were collected from the contaminated agricultural fields of the South China Agricultural University, Guangzhou, China and used to isolate fungi that degrade allethrin. Collected soil samples were stored at $4{ }^{\circ} \mathrm{C}$ for further use. Enrichment and isolation of the allethrin-degrading strain was carried out in MSM using enrichment culture techniques [33-37]. The fungal colonies of 
different morphologies were collected and purified with the streaking method. The isolated strains were further screened for their abilities to degrade allethrin. The pure fungal isolate with the highest allethrin degradation ability was designated as CF2 for further study.

\subsection{Identification of the Strain CF2}

The fungal isolate CF2 was grown in CDM agar media and investigated by a light microscope. The colonies were observed with the microscope on different days. Total genomic DNA of the strain CF2 was isolated using an OMEGA fungal DNA extraction mini kit (Omega Bio-Tek, Norcross, GA, USA). The 5.8 S rDNA gene was amplified using polymerase chain reaction (PCR) with the universal primer sets ITS-5 (5'-GGAAGTAAAAGTCGTAACAAGG-3') and ITS-4 (5'-GCATATCAATAAGCGGAGGA-3') [17]. The conditions for PCR was as follows-initial denaturation at $95^{\circ} \mathrm{C}$ up to $3 \mathrm{~min}$, followed by 35 cycles of reactions with denaturation at $94^{\circ} \mathrm{C}$ for $1 \mathrm{~min}$, annealing at $55^{\circ} \mathrm{C}$ for $1 \mathrm{~min}$, and extension at $72{ }^{\circ} \mathrm{C}$ for $1 \mathrm{~min}$. The last cycle was followed by $10 \mathrm{~min}$ extension at $72^{\circ} \mathrm{C}$. The PCR products were observed in $1 \%$ agarose gel electrophoresis with a $2 \mathrm{~Kb}$ marker and sent for sequencing. The resulting sequences were compared with the GenBank submitted sequence database using the National Centre for Biotechnology Information (NCBI) BLAST search. Multiple sequence alignment was performed among sequences using the Clustal-W offline tool. Phylogenetic analysis was performed using the MEGA-X software (Pennsylvania State University, University Park, PA, USA). The phylogenetic tree of all of the sequences was formed using unweighted pair group method with arithmetic mean (UPGMA) techniques.

\subsection{Preparation of Fungal Inoculum}

The fungal strain CF2 was grown in $50 \mathrm{~mL}$ of CDM for two days at $28^{\circ} \mathrm{C}$, with a shaking speed of $200 \mathrm{rpm}$. The mycelia of strain CF2 were harvested using centrifugation at $5000 \mathrm{rpm}$ for $10 \mathrm{~min}$ and washed with $0.9 \%$ sterile saline [38]. The washed mycelia were resuspended in $50 \mathrm{~mL}$ saline; $5 \mathrm{~mL}$ of this suspension was used as inoculum for allethrin degradation.

\subsection{Optimization of the Degradation Conditions for Strain CF2}

To study the effects of temperature and $\mathrm{pH}$ on the growth/degradation of allethrin by strain $\mathrm{CF} 2$, a single-factor experiment was designed under different temperatures $\left(18,22,26,30,34{ }^{\circ} \mathrm{C}\right)$ and $\mathrm{pH}(4.0,5.0,6.0,7.0,8.0)$ conditions. Strain CF2 was incubated in MSM (pH 6.0) containing $50 \mathrm{mg} \cdot \mathrm{L}^{-1}$ allethrin at $26^{\circ} \mathrm{C}$ at $110 \mathrm{rpm}$ on a rotary shaker for 5 days. Each treatment was performed in triplicate with noninoculated samples as a control [21]. The growth of strain CF2 was determined by measurement of the dry weight of the mycelium. The residual concentration of allethrin was analyzed by high-performance liquid chromatography (HPLC) (Waters e2695, Milford, MA, USA).

The culture conditions for allethrin degradation were further optimized by response surface methodology (RSM) with strain CF2. The pH, temperature, and time of incubation were considered as significant for allethrin degradation, based on the results of previous single-factor experiments [39,40]. Central composite design (CCD) of five levels $(-1.68,-1,0,+1,+1.68)$ was used for optimization with 24 experiments with three replicates of Design Expert-11 software. The used variables were coded according to the following Equation (1):

$$
x_{\mathrm{i}}=\left(X_{\mathrm{i}}-X_{0}\right) / \Delta X_{\mathrm{i}}
$$

where $x_{\mathrm{i}}$ is the dimensionless value of an independent variable; $X_{\mathrm{i}}$ is the real value of an independent variable; $X_{0}$ is the real value of an independent variable at the center point; and $\Delta X_{\mathrm{i}}$ is the step change of the real value of a variable.

Allethrin $\left(50 \mathrm{mg} \cdot \mathrm{L}^{-1}\right)$ degradation in $50 \mathrm{~mL}$ MSM was considered as the dependent variable after 5 days. Data were analyzed by a regression procedure of RSM to fit the quadratic polynomial Equation (2).

$$
Y_{\mathrm{i}}=b_{0}+\sum b_{\mathrm{i}} X_{\mathrm{i}}+\sum b_{\mathrm{ij}} X_{\mathrm{i}} X_{\mathrm{j}}+\sum b_{\mathrm{ii}} X^{2}{ }_{\mathrm{i}}
$$


where $Y_{\mathrm{i}}$ is predicted response, $X_{\mathrm{i}}$ and $X_{\mathrm{j}}$ are variables, $b_{0}$ is constant, $b_{\mathrm{i}}$ is the linear coefficient, $b_{\mathrm{ij}}$ is the interaction coefficient and $b_{\mathrm{ii}}$ is the quadratic coefficient.

\subsection{Degradation Kinetics of Allethrin with Strain CF2}

To check the degradation kinetics of allethrin, strain CF2 was inoculated in the MSM under the influence of optimal culture conditions. The final concentration of $50 \mathrm{~mL} \mathrm{MSM}$ in a $250 \mathrm{~mL}$ Erlenmeyer flask was $50 \mathrm{mg} \cdot \mathrm{L}^{-1}$. The flasks were incubated in triplicate with a control at $26{ }^{\circ} \mathrm{C}$ for up to $144 \mathrm{~h}$. The samples were collected at $24 \mathrm{~h}$ intervals and the residual concentration was determined by HPLC. The growth of strain CF2 was determined by measurement of the dry weight of the mycelium. Each treatment was set in triplicate with noninoculated samples as a control [41].

\subsection{Extraction and HPLC Analysis}

The allethrin and its intermediate metabolites after degradation were extracted using acetone and ethyl acetate methods. Ten milliliters of the MSM after different days of the experiment was collected in $50 \mathrm{~mL}$ tubes. Furthermore, $10 \mathrm{~mL}$ of acetone was added in each of the tubes, followed by ultrasonication for $15 \mathrm{~min}$. The $10 \mathrm{~mL}$ of ethyl acetate was added in the sonicated samples and vortexed well. The separated layer of the organic and aqueous phase was clearly distinguished, and the organic phase was collected in new tubes. Again, the $10 \mathrm{~mL}$ of ethyl acetate was added for complete recovery of the allethrin from the samples. Then, $10 \mathrm{~g}$ of anhydrous sodium sulfate was added to each of the tubes and vortexed. All of the tubes were centrifuged at $8000 \mathrm{rpm}$ for $4 \mathrm{~min}$. Then, the samples were evaporated under a vacuum in round-bottom flasks, and the recovery of allethrin and its metabolites were used for HPLC analysis [23,42-45].

HPLC was used for the quantitative analysis of allethrin residue in each experiment throughout the work. HPLC was attached with a UV detector and a $\mathrm{C}_{18}$ reversed column, and a column oven was used for the detection and quantification of allethrin. The mobile phase was composed of deionized water and acetonitrilem, which was filtered before use, using a $0.45 \mu \mathrm{m}$ filter under vacuum pressure. The prepared mobile phase was set in acetonitrile (65)/water (35) with a flow rate of $0.7 \mathrm{~mL} \cdot \mathrm{min}^{-1}$ and the pump mode was isocratic. The volume used for sample injection was $20 \mu \mathrm{L}$. UV detection was carried out at $250 \mathrm{~nm}$, with a $34 \mathrm{~min}$ running time.

\subsection{Kinetic Analysis}

The allethrin degradation parameters were calculated as per first-order reaction kinetics [21,46-48].

$$
C_{t}=C_{0} e^{-k t}
$$

where $C_{0}$ is the initial concentration of allethrin in MSM, $C_{t}$ is the concentration of allethrin at time $t, k$ is the degradation rate constant $\left(\mathrm{h}^{-1}\right)$, and $t$ is the reaction time $(\mathrm{h})$.

The degradation half-life $\left(t_{1 / 2}\right)$ of allethrin was determined as Equation (4).

$$
t_{1 / 2}=\ln 2 / k
$$

\subsection{Statistical Analysis}

Statistical data regarding allethrin degradation in all of the experimental sets were subjected to two-way analysis of variance (ANOVA) to calculate the effects of the treatments on allethrin degradation. Allethrin concentration and fungi treatments were considered as first and second factors, respectively. The critical difference (CD), calculated at the $5 \%$ level of significance, was used to compare the differences among treatment means. The statistical analysis of allethrin biodegradation was carried out in IBM-SPSS version 20.0, USA. 


\section{Results}

\subsection{Isolation and Identification of Strain CF2}

After four rounds of enrichment at different allethrin concentrations (50-1000 $\left.\mathrm{mg} \cdot \mathrm{L}^{-1}\right)$, six fungal isolates were recovered from the soil samples. The fungal isolate designated as CF2 was selected and screened on the basis of its potential allethrin degradation abilities for further experiment. The fungus efficiently degraded and metabolized allethrin up to concentrations as high as $1000 \mathrm{mg} \cdot \mathrm{L}^{-1}$ in $\mathrm{MSM}$. Strain CF2 is an obligatory aerobic fungus with spore-forming potential. Its colonies are white, with dense mycelia and rounds covering the entire CDM plates (Supplementary Figures S1 and S2). Phylogenetic analysis of 5.8 S rDNA gene confirmed that strain CF2 has a high similarity to Fusarium proliferatum (Figure 1). The GenBank accession number of the submitted strain CF2 is MN 658457.1. Based on morphology and molecular tools, strain CF2 was identified as F. proliferatum.

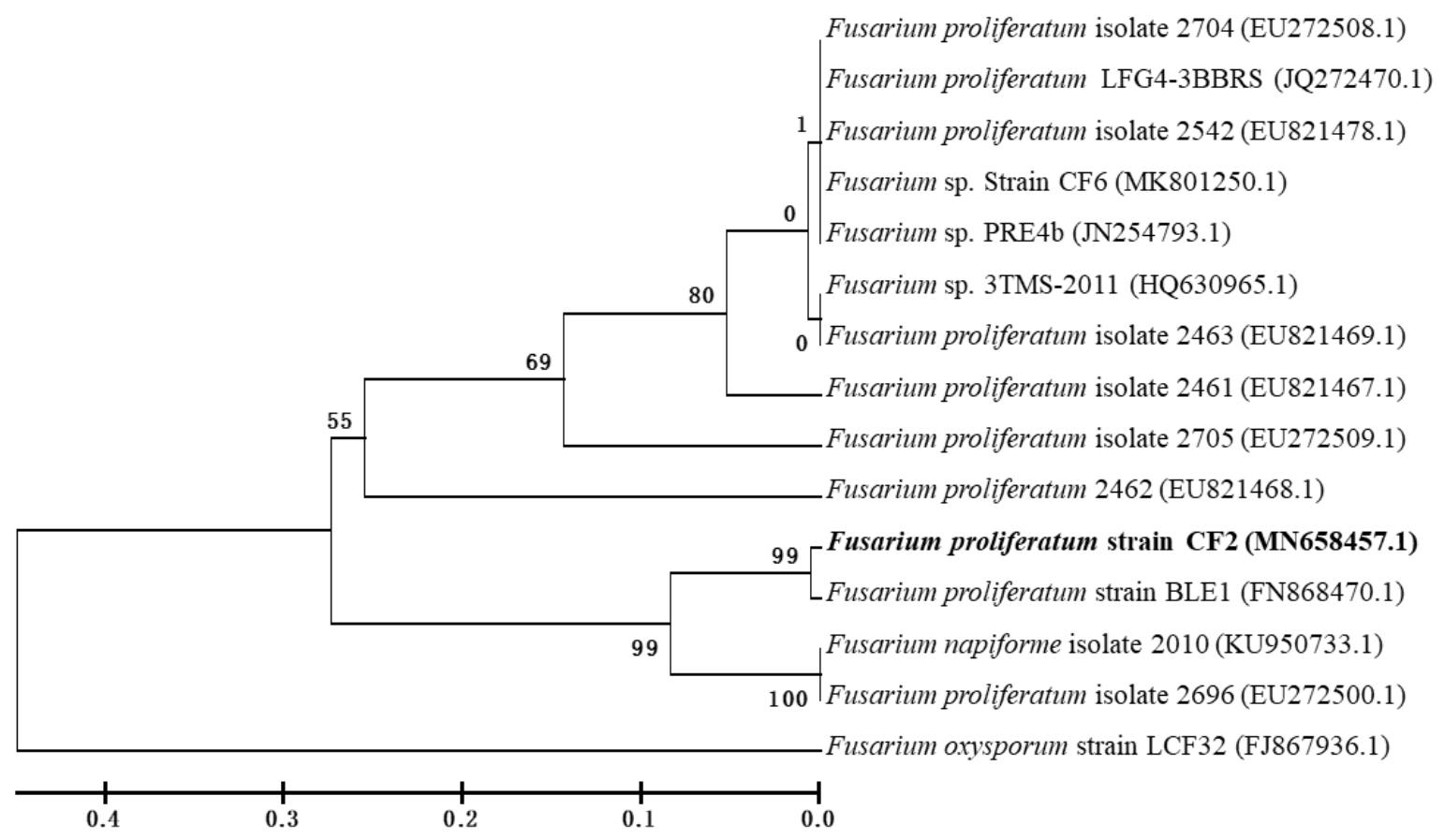

Figure 1. Phylogenetic relationships of the isolated strain CF2 and other closely related species on the basis of 5.8S rRNA sequences. The numbers at the nodes represent the accession numbers of GenBank. The bootstrap value for the unweighted pair group method with arithmetic mean (UPGMA) phylogenetic tree was 1000 .

\subsection{Optimization of Allethrin Degradation Conditions}

Strain CF2 effectively degraded allethrin under different temperatures and $\mathrm{pH}$ conditions (Figure 2). It degraded $73.1 \%, 87.9 \%, 95.0 \%, 91.3 \%$, and $84.2 \%$ of allethrin at $18,22,26,30$, and $34{ }^{\circ} \mathrm{C}$ within 5 days, respectively. A total of $89.2 \%, 91.0 \%, 95.3 \%, 91.7 \%$, and $89.4 \%$ degradation was achieved at $\mathrm{pH} 4.0,5.0$, 6.0, 7.0, and 8.0, respectively. Maximum degradation and mycelium dry weight were both observed at a temperature of $26^{\circ} \mathrm{C}$ and $\mathrm{pH} 6.0$. 
a

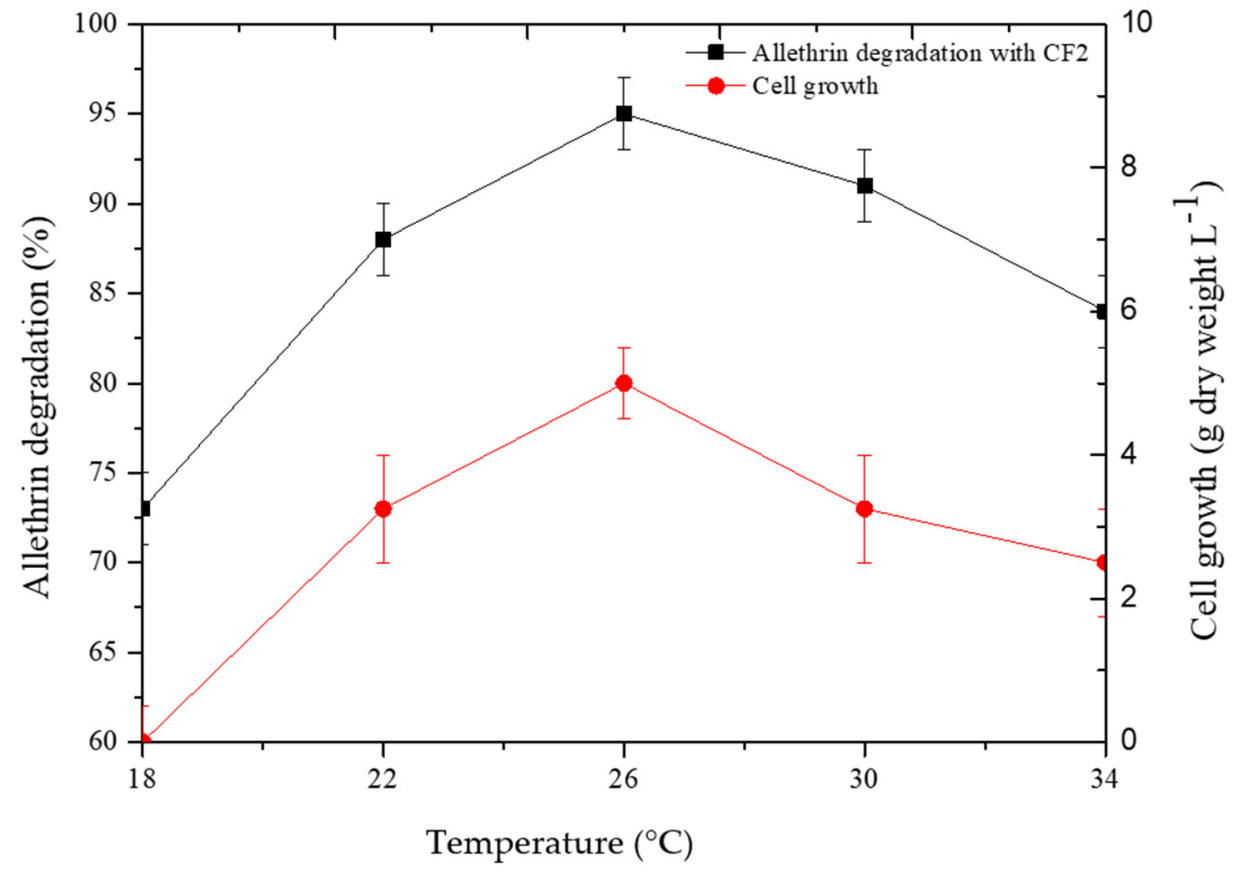

b

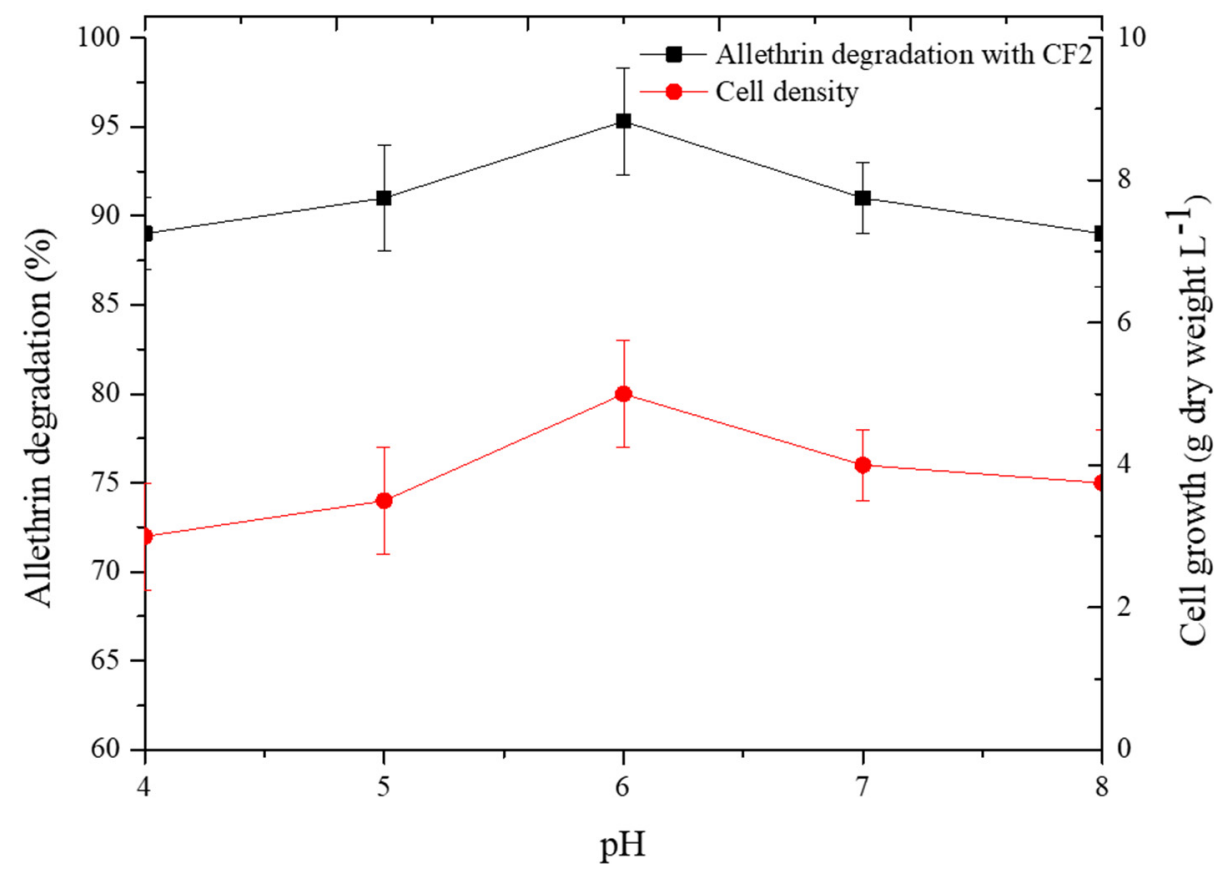

Figure 2. Effect of temperature (a) and $\mathrm{pH}(\mathbf{b})$ on the degradation of allethrin by strain $\mathrm{CF} 2$. The data presented are mean \pm standard errors of three independent experiments.

Central composite design (CCD) of response surface methodology (RSM) was further used to investigate the effects of each of the parameters on allethrin degradation (Supplementary Figure S3). The interactive effects of the $\mathrm{pH}(\mathrm{A})$, temperature (B), and culture time (C) on allethrin degradation were determined with strain CF2. The matrix of the design used with the optimized responses is given in Table 1. The data of 24 experiments were used for analysis with Design Expert-11. The results of quadratic polynomial model fitting in terms of analysis of variance (ANOVA) are shown in Supplementary Table S1. The $R^{2}$ value 0.9823 , showing the predicted value of model, is consistent with the experimental values. The $F$-value of 143.23 and a $p$-value $<0.05$ indicates that the model 
parameters are statistically significant. Regression-based analysis of the experimental data formulated the following coded quadratic polynomial equation explaining allethrin degradation.

$$
\begin{gathered}
\mathrm{Y}=94.23-0.1231 \times \mathrm{A}-0.2929 \times \mathrm{B}+4.04 \times \mathrm{C}-1.25 \times \mathrm{AB}+2.00 \times \mathrm{AC}-4.50 \times \mathrm{BC}- \\
6.74 \times \mathrm{A}^{2}-6.91 \times \mathrm{B}^{2}-5.11 \times \mathrm{C}^{2}
\end{gathered}
$$

where $\mathrm{Y}=\%$ allethrin degradation using the strain $\mathrm{CF} 2$; and $\mathrm{A}, \mathrm{B}$, and $\mathrm{C}$ are the coded terms for $\mathrm{pH}$, temperature $\left({ }^{\circ} \mathrm{C}\right)$, and incubation time (days), respectively. The statistical significance of the data was evaluated using $F$ test and $t$-test. All of the statistical analyses suggest that the model linear term coefficients of A, B, and C showed significant effects $(p<0.05)$ on allethrin degradation. The coefficient estimates represent the expected change in response per unit change in factor value when all remaining factors were held constant. The predicted $R^{2}$ value 0.9412 supports the applied model. The results show that there is a good correlation between the predicted value of the model and the experimental value. The low coefficient of variation $(\mathrm{CV}=1.64)$ demonstrates the good precision and reliability of the performed experiment. Thus, the developed model could be adequate for the determination of a range of variables.

Table 1. Central composite design (CCD) for the optimization of allethrin degradation using strain CF2.

\begin{tabular}{ccccc}
\hline Run & $\boldsymbol{X}_{\mathbf{1}}$ & $\boldsymbol{X}_{\mathbf{2}}$ & $\boldsymbol{X}_{\mathbf{3}}$ & $\begin{array}{c}\text { Allethrin } \\
\text { Degradation (\%) }\end{array}$ \\
\hline 1 & +1 & +1 & -1 & $76.0 \pm 0.88^{\mathrm{d}}$ \\
2 & 0 & 0 & 0 & $93.0 \pm 0.57^{\mathrm{g}}$ \\
3 & 0 & 0 & -1.68 & $75.0 \pm 1.10^{\mathrm{d}}$ \\
4 & 0 & 0 & 0 & $93.0 \pm 1.70^{\mathrm{g}}$ \\
5 & +1 & -1 & -1 & $69.0 \pm 0.57^{\mathrm{b}}$ \\
6 & -1 & -1 & -1 & $64.0 \pm 0.57^{\mathrm{a}}$ \\
7 & 0 & 0 & 0 & $94.5 \pm 0.28^{\mathrm{ghi}}$ \\
8 & 0 & 0 & 0 & $95.5 \pm 0.28^{\mathrm{hi}}$ \\
9 & -1 & +1 & -1 & $73.0 \pm 0.00^{\mathrm{c}}$ \\
10 & 0 & 0 & 0 & $95.6 \pm 0.57^{\mathrm{i}}$ \\
11 & -1.68 & 0 & 0 & $76.0 \pm 0.57^{\mathrm{d}}$ \\
12 & 0 & 0 & 0 & $93.5 \pm 0.57^{\mathrm{gh}}$ \\
13 & 0 & 0 & 0 & $93.0 \pm 0.57^{\mathrm{g}}$ \\
14 & 0 & +1.68 & 0 & $75.0 \pm 0.57^{\mathrm{d}}$ \\
15 & -1 & +1 & +1 & $79.0 \pm 0.57^{\mathrm{e}}$ \\
16 & 0 & 0 & 0 & $94.3 \pm 0.03^{\mathrm{ghi}}$ \\
17 & -1 & -1 & +1 & $85.0 \pm 0.00^{\mathrm{f}}$ \\
18 & 0 & 0 & +1.68 & $85.2 \pm 0.11^{\mathrm{f}}$ \\
19 & +1 & +1 & +1 & $71.0 \pm 0.60^{\mathrm{c}}$ \\
20 & 0 & -1.68 & 0 & $75.0 \pm 0.00^{\mathrm{d}}$ \\
21 & +1 & -1 & +1 & $85.0 \pm 0.00^{\mathrm{f}}$ \\
22 & 0 & 0 & 0 & $95.3 \pm 0.57^{\mathrm{hi}}$ \\
23 & +1.68 & 0 & 0 & $75.0 \pm 0.57^{\mathrm{d}}$ \\
24 & 0 & 0 & 0 & $94.5 \pm 0.28^{\mathrm{ghi}}$ \\
\hline
\end{tabular}

Note: Data presented are the means of three replicates with standard error. Different letters indicate significant differences $(p<0.005$, least significant (LSD) test) according to the Duncan test.

The three-dimensional response surface plots of all of the variables determined the effect of each parameter with interactive points for allethrin degradation with strain CF2 (Figure 3). This model predicted a maximum allethrin degradation of $95.6 \%$ at the stationary point. The optimum points for degradation in the model for $\mathrm{A}, \mathrm{B}$, and $\mathrm{C}$ were 0,0 , and 0 in terms of coded units corresponding to $\mathrm{pH} 6.0$, temperature $26^{\circ} \mathrm{C}$, and an incubation time of 5 days, respectively. The contour plot and cube represent graphs showing the interactive effect of each of the parameters in allethrin degradation with strain CF2 (Figure 4). The center point in the contour plot with run 10 represents the maximum 
allethrin degradation. The detailed analysis each of the 24 runs with the actual value, predicted value, residuals, leverage, and cooks distance supports the degradation of allethrin being highly significant with strain CF2. The cook's distance for the treatments was in the range of $0.01-0.048$. The statistical values calculated for the model suggest that the model is effective for allethrin degradation with fungal strain CF2. The residuals vs. run and the predicted analysis represent the lurking variables that influence allethrin degradation using strain CF2. The externally studentized residuals were calculated from -3.8 to $+3.8(p<0.05)$ for all of the treatments with strain CF2 during allethrin degradation. Furthermore, Box-Cox analysis shows that the used model justifies the best degradation model for allethrin degradation (Figure 5).

a

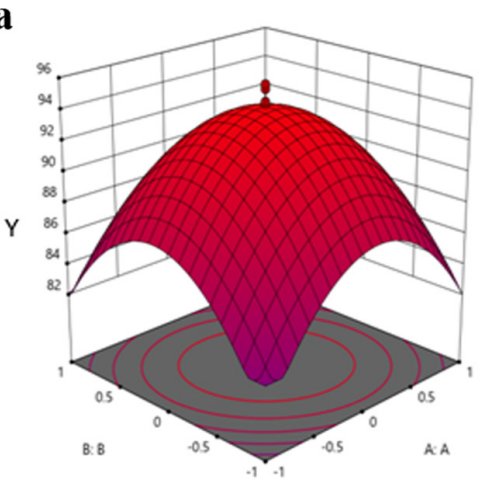

b

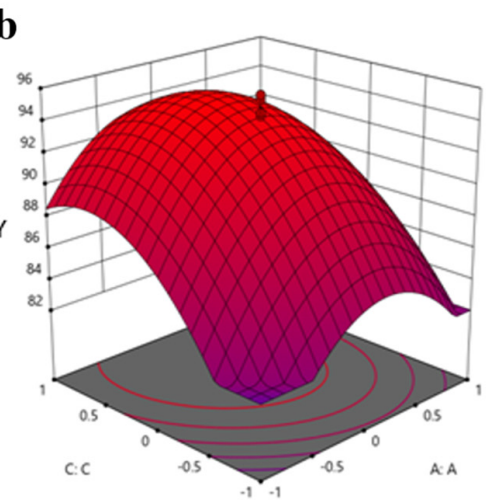

c

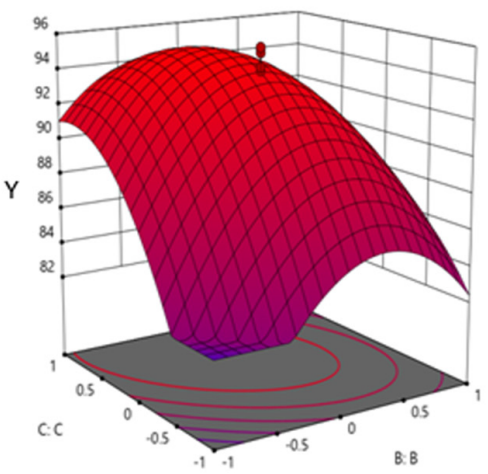

Figure 3. Optimization of the allethrin degradation condition using response surface methodology. Response surface plots showing the interactive effects of $\mathrm{pH}(\mathbf{a})$, temperature (b), and incubation time (c) on allethrin degradation (Y) with strain CF2.
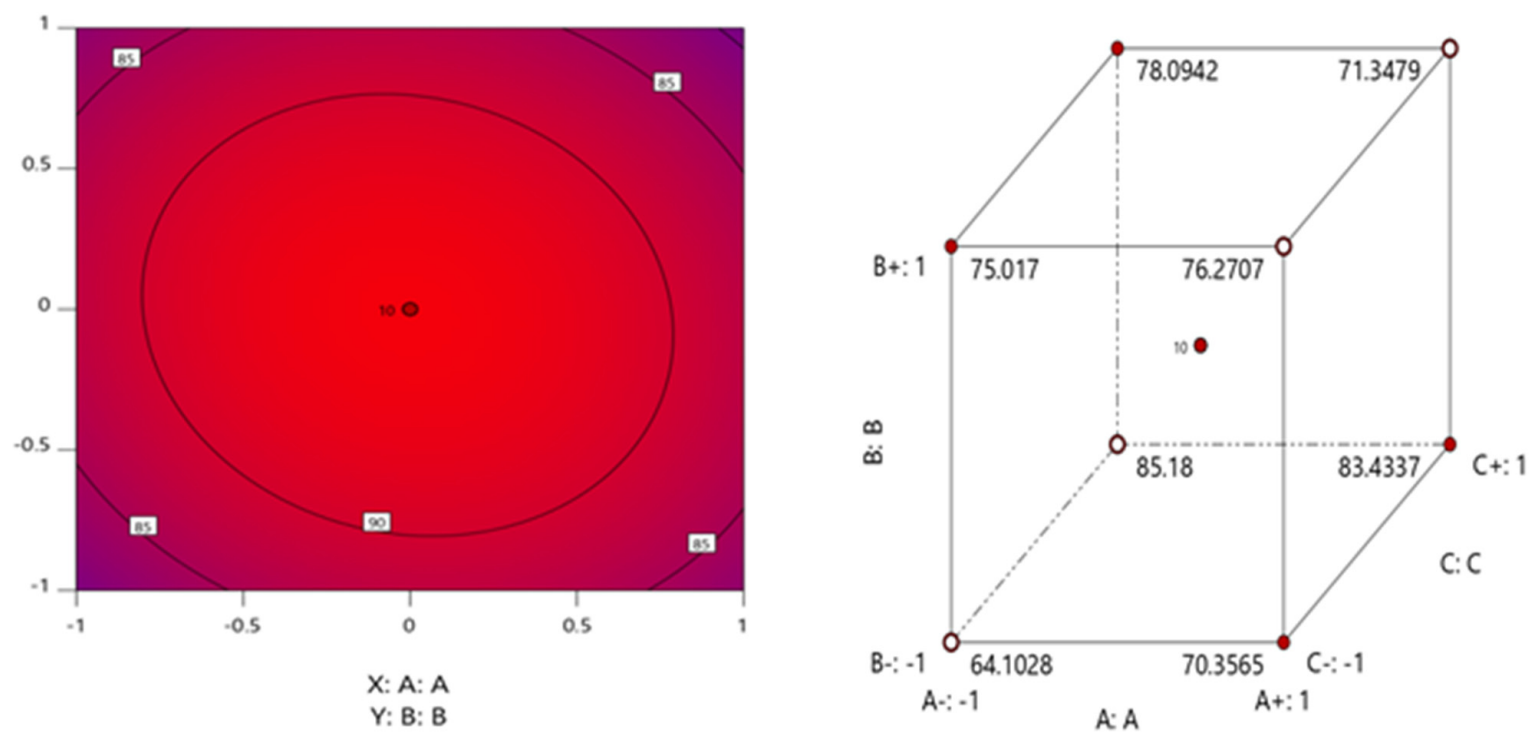

Figure 4. Contour plot representing the center-optimized point for allethrin degradation, and the cube structure representing the effects of $\mathrm{pH}(\mathbf{A})$, temperature $(\mathbf{B})$, and incubation time $(\mathbf{C})$ on allethrin degradation. 


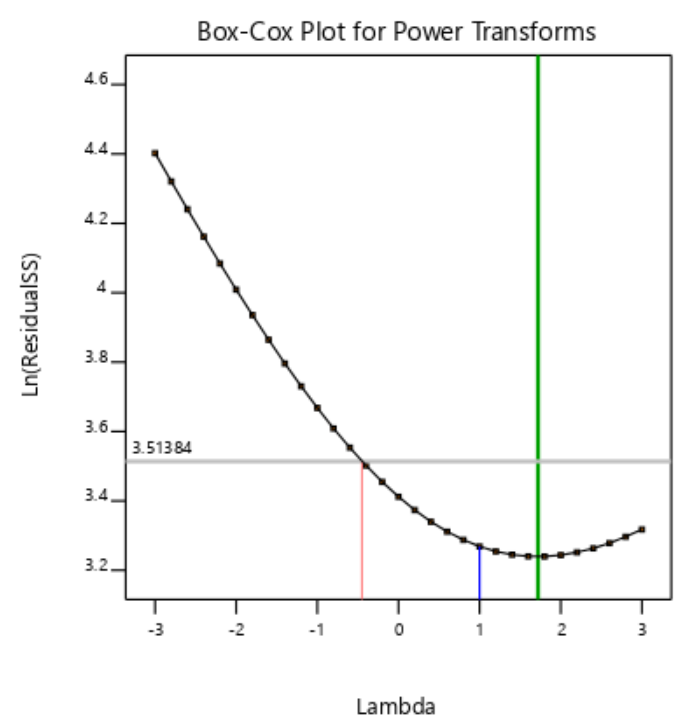

Figure 5. A Box-Cox plot representing the correlation coefficients for various optimized conditions. The green line shows the best lambda at value 1.72 . The class interval for lambda $(-0.45,4.24)$ are shown. Values are mean \pm SEM of triplicates and are significant at $p<0.05$ for all treatments.

\subsection{Degradation Kinetics of Allethrin with Strain CF2}

Kinetics-based analysis of allethrin degradation was observed with different time intervals. The degradation kinetics of allethrin with strain CF2 are shown in Figure 6. Strain CF2 rapidly degraded allethrin after inoculation in the MSM. We observed that $95.6 \%$ of allethrin $\left(50 \mathrm{mg} \cdot \mathrm{L}^{-1}\right)$ was degraded within $120 \mathrm{~h}$ of the experiment without a lag phase. After $144 \mathrm{~h}$, no allethrin residue was found in the experimental group. However, the dissipation of noninoculated control was only $18.0 \%$. Microbial degradation was associated with mycelial growth. Mycelial growth was highest during the first $24 \mathrm{~h}$ of incubation and a maximum mycelium dry weight was observed after $72 \mathrm{~h}$.

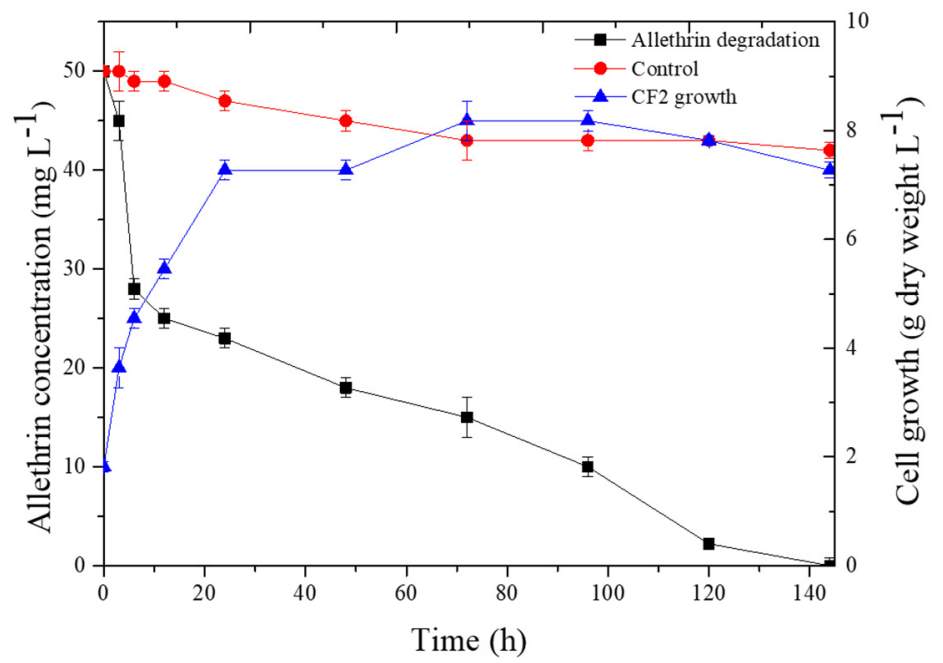

Figure 6. Growth curves of strain CF2 and allethrin degradation profiles over time. The data presented are mean \pm standard errors of three independent experiments.

The kinetic parameters were calculated with strain CF2. The degradation rate constant $(k)$ and half-time $\left(t_{1 / 2}\right)$ for the control were calculated as $0.0013 \mathrm{~h}^{-1}$ and $533.19 \mathrm{~h}$, respectively, whereas for CF2-treated samples, these values were $0.0193 \mathrm{~h}^{-1}$ and $26.05 \mathrm{~h}$, respectively. The determination coefficient $\left(R^{2}\right)$ was 0.926 and 0.850 for the control and CF2 treatment group, respectively. These results 
confirm that inoculation with strain CF2 significantly accelerated allethrin degradation in MSM. At the end of the experiment, allethrin was completely degraded by the F. proliferatum strain CF2.

\section{Discussion}

Due to the large-scale use of allethrin at various agricultural locations and in the home, residual concentrations are increasing day-by-day and are causing hazardous effects on living cells in the environment. Bioremediation was previously found to be the most promising approach for the removal of pesticide residues from the environment [49-54]. In the present study, a novel fungal strain CF2, which was identified as F. proliferatum, responsible for degradation of allethrin, was isolated from pesticide-contaminated agricultural fields. To date, the degradation assay information about allethrin is very limited. No one has characterized the fungi-based degradation of allethrin, and to the best of our knowledge, this is the first report on this topic.

Scant information is available for the degradation of pyrethroids and other pesticides using fungi. Previously, Trichoderma, Aspergillus, Eurotium, Candida, and Phanerochaete have been reported to degrade pyrethroids [22-25,55]. Eurotium cristatum ET1, a fungus from fu brick tea in China, was found to degrade $\beta$-cypermethrin and 3-phenoxybenzaldehye [55]. Pyrethroid-degrading fungi Cunninghamella elegans was characterized for the degradation of cyhalothrin [25]. Fungi have the great potential to degrade xenobiotics from the environment by chemical modification and by influencing the bioavailability [56]. However, there is still little attention given to fungi in pesticide degradation as compared to bacteria. On the basis of biomass fungi dominating the kingdom in soil and the aqueous system, they deserve special attention for pesticide degradation $[27,57]$. Naturally, fungi are found to be more advantageous than bacteria for the degradation of recalcitrant compounds $[20,58]$. To identify effective fungi for pesticide degradation, our group identified Cladosporium and Candida for the degradation of pesticides [22,27,35]. However, the potential use of F. proliferatum in biodegradation of pesticides has not received the attention it deserves. Our studies, focused on F. proliferatum, showed that it could utilize allethrin as the sole source of carbon for growth, and thus it can be successfully colonized in nutrient-deficient niches.

We observed that the F. proliferatum strain CF2 has the ability to degrade allethrin at a wide variety of $\mathrm{pH}$ levels, temperatures, and incubation times. These characteristics of strain CF2 may be beneficial for the degradation at various naturally contaminated sites due to its survival in different conditions. Previous studies have confirmed that fungal strains that can perform good degradation in adverse conditions could also be beneficial for in situ remediation in indigenous environments [27,35]. Under high acidic environments, strain CF2 did not perform well in degradation. These results are consistent with previous findings that reported that rapid degradation was liable to happen under neutral- and alkaline-trending conditions $[36,59,60]$. Indeed, our results imply that the synthesis and expression of the degradation enzyme of strain CF2 may perform better under neutral- and alkaline-trending conditions. The strain CF2 participated in efficient degradation of allethrin in adverse environments, which suggests that it may be used as a suitable candidate for the bioremediation of allethrin and other pyrethroids.

RSM was used for optimization of the degradation condition with strain CF2. RSM is an analytical tool for the optimization of various biological processes and has been used previously with bacterial and fungal process optimization [18,22,36,39]. Previous studies support the use of RSM in pesticide degradation as being useful for the optimization of processes with precision [61-64]. In our study, we conducted a detailed analysis of allethrin degradation with a central composite design of RSM. The results showed that the optimum degradation conditions for strain CF2 were $\mathrm{pH} 6.0$, temperature $26{ }^{\circ} \mathrm{C}$, and an incubation time of 5 days. Under these conditions, strain CF2 degraded allethrin $\left(50 \mathrm{mg} \cdot \mathrm{L}^{-1}\right)$ by up to $95.6 \%$ within 5 days. The contour plot, cube, residual vs. predicted, and Box-Cox plot etc. analyses confirmed that the used model is efficient for allethrin degradation optimization. Similar results were previously observed on Cladosporium sp. HU for the degradation of fenvalerate [22]. 
It is noteworthy that the fungal strain CF2 tolerated and degraded high concentrations of allethrin up to $1000 \mathrm{mg} \cdot \mathrm{L}^{-1}$, which is rarely seen in other microbial strains. In most cases reported to date, the pyrethroid-degrading strains are often inhibited by high concentrations of substrates [65-68]. Previous studies indicated that the metabolic activity of pyrethroid-degrading microorganisms resulted in complete catabolite repression at high substrate concentrations $<200 \mathrm{mg} \cdot \mathrm{L}^{-1}[18,66,69]$. In contrast, high concentration of allethrin $\left(1000 \mathrm{mg} \cdot \mathrm{L}^{-1}\right)$ did not inhibit the cell growth of strain CF2, and more importantly the enhanced biodegradation was observed even at the high concentration of allethrin. Moreover, kinetics analysis showed that allethrin half-life was substantially reduced by $507.1 \mathrm{~h}$, as compared to the noninoculated control. The degradation rate constant $\left(0.0193 \mathrm{~h}^{-1}\right)$ was much greater than those by other pyrethroid-degrading strains [15,34,43,48]. These findings suggested F. proliferatum CF2 has an exceptional ability to degrade allethrin in different ecological niches, which makes it a potent strain for various applications.

\section{Conclusions}

A novel isolated fungal strain, F. proliferatum CF2, has the ability to degrade allethrin rapidly without a lag period of growth. This is the first report of biodegradation of allethrin using F. proliferatum. The culture conditions of strain CF2 were optimized, and it was found that strain CF2 effectively degraded allethrin over broad $\mathrm{pH}$ and temperature ranges. These characteristics indicate that strain CF2 has the potential to bioremediate allethrin-contaminated environments. Furthermore, strain CF2 revealed a remarkable capacity to obtain nutrients by metabolizing allethrin without an extra carbon source. Kinetics analysis showed that the $t_{1 / 2}$ of allethrin with strain CF2 substantially decreased in MSM, from 533.2 to 26.1 hours. These results highlight the promising potential of F. proliferatum CF2 in the bioremediation of allethrin-contaminated sites. Furthermore, in enzymatic- and metabolic-based work, it could be more advantageous to understand the detailed mechanism of allethrin degradation with the CF2 strain.

Supplementary Materials: Supplementary materials can be found at http://www.mdpi.com/2076-2607/8/4/593/s1.

Author Contributions: Conceptualization, S.C.; methodology, P.B.; data analysis, P.B.; writing-original draft preparation, P.B.; writing-review and editing, W.Z., Z.L., S.P., Y.H., and S.C.; supervision, funding acquisition, and project administration, S.C. All authors have read and agreed to the published version of the manuscript.

Funding: This study was funded by the Key-Area Research and Development Program of Guangdong Province (2018B020206001), the National Natural Science Foundation of China (31401763), and the Guangdong Special Branch Plan for Young Talent with Scientific and Technological Innovation (2017TQ04N026).

Conflicts of Interest: The authors declare no conflicts of interest. The funders had no role in the design of the study; in the collection, analyses, or interpretation of data; in the writing of the manuscript; or in the decision to publish the results.

\section{References}

1. Wolansky, M.J.; Harrill, J.A. Neurobehavioral toxicology of pyrethroid insecticides in adult animals: A critical review. Neurotoxicol. Teratol. 2008, 30, 55-78. [CrossRef] [PubMed]

2. Paingankar, M.; Jain, M.; Deobagkar, D. Biodegradation of allethrin, a pyrethroid insecticide, by an Acidomonas sp. Biotechnol. Lett. 2005, 27, 1909-1913. [CrossRef] [PubMed]

3. Na, H.Y.; Kim, Y.D.; Choi, Y.S.; Choi, Y.S.; Bae, C.H.; Song, Y.S. Allethrin and prallethrin stimulates MUC5AC expression through oxidative stress in human airway epithelial cells. Biochem. Biophysi. Res. Commun. 2018, 503, 316-322. [CrossRef] [PubMed]

4. Madhubabu, G.; Yenugu, S. Allethrin toxicity causes reproductive dysfunction in male rats. Environ. Toxicol. 2017, 32, 1701-1710. [CrossRef]

5. Zhan, H.; Huang, Y.; Lin, Z.; Bhatt, P.; Chen, S. New insights into the microbial degradation and catalytic mechanism of synthetic pyrethroids. Environ. Res. 2020, 182, 109138. [CrossRef]

6. Cycon, M.; Piotrowska-Seget, Z. Pyrethroid-degrading microorganisms and their potential for the bioremediation of contaminated soils: A review. Front. Microbiol. 2016, 7, 1463. [CrossRef] 
7. Aznar-Alemany, Ò.; Eljarrat, E. Introduction to Pyrethroid Insecticides: Chemical Structures, Properties, Mode of Action and Use. In The Handbook of Environmental Chemistry; Springer: Berlin/Heidelberg, Germany, 2020.

8. Bradberry, S.M.; Cage, S.A.; Proudfoot, A.T.; Vale, J.A. Poisoning due to pyrethroids. Toxicol. Rev. 2005, 24, 93-106. [CrossRef]

9. Possetto, D.; Natera, J.; Sancho, M.I.; García, N.A.; Massad, W.A. Bioallethrin degradation by photo-fenton process in acetonitrile/water and aqueous $\beta$-cyclodextrin solutions. J. Photochem. Photobiol. Chem. 2018, 365, 103-109. [CrossRef]

10. Arif, A.; Salam, S.; Mahmood, R. Bioallethrin-induced generation of reactive species and oxidative damage in isolated human erythrocytes. Toxicol. In Vitro 2020, 65, 104810. [CrossRef]

11. Hossain, M.M.; Suzuki, T.; Sato, I.; Takewaki, T.; Suzuki, K.; Kobayashi, H. Neuromechanical effects of pyrethroids, allethrin, cyhalothrin and deltamethrin on the cholinergic processes in rat brain. Life Sci. 2005, 77, 795-807. [CrossRef]

12. Ramos-Chavez, L.A.; Sordo, M.; Calderon-Aranda, E.; Castañeda-Saucedo, E.; Ostrosky-Wegman, P.; Moreno-Godinez, M.E. A permethrin/allethrin mixture induces genotoxicity and cytotoxicity in human peripheral blood lymphocytes. J. Toxicol. Environ. Heal. Part A Curr. Issues 2015, 78, 7-14. [CrossRef] [PubMed]

13. Srivastava, A.K.; Srivastava, P.K.; Al-Khedhairy, A.A.; Musarrat, J.; Shukla, Y. Allethrin-induced genotoxicity and oxidative stress in swiss albino mice. Mutat. Res. 2012, 747, 22-28. [CrossRef] [PubMed]

14. Gupta, G.; Chaitanya, R.K.; Golla, M.; Karnati, R. Allethrin toxicity on human corneal epithelial cells involves mitochondrial pathway mediated apoptosis. Toxicol. In Vitro 2013, 27, 2242-2248. [CrossRef] [PubMed]

15. Huang, Y.; Lin, Z.; Zhang, W.; Pang, S.; Bhatt, P.; Rene, E.R.; Kumar, A.J.; Chen, S. New insights into the microbial degradation of $D$-cyphenothrin in contaminated water/soil environments. Microorganims 2020, 8 , 473. [CrossRef]

16. Gangola, S.; Khati, P.; Sharma, A. Mycoremediation of imidaclopridin the presence of different soil amendments using Trichoderma longibrachiatum and Aspergillus oryzae isolated from pesticide contaminated agricultural fields of Uttarakhand. J. Biorem. Biodegredation 2015, 6, 2-5.

17. Narendra, M.; Kavitha, G.; Helah Kiranmai, A.; Raghava Rao, N.; Varadacharyulu, N.C. Chronic exposure to pyrethroid-based allethrin and prallethrin mosquito repellents alters plasma biochemical profile. Chemosphere 2008, 73, 360-364. [CrossRef]

18. Yang, J.; Feng, Y.; Zhan, H.; Liu, J.; Yang, F.; Zhang, K.; Zhang, L.; Chen, S. Characterization of a pyrethroid-degrading Pseudomonas fulva strain P31 and biochemical degradation pathway of D-phenothrin. Front. Microbiol. 2018, 9, 1003. [CrossRef]

19. Bhatt, P.; Huang, Y.; Zhan, H.; Chen, S. Insight into microbial applications for the biodegradation of pyrethroid insecticides. Front. Microbiol. 2019, 10, 1778. [CrossRef]

20. Gangola, S.; Joshi, S.; Kumar, S.; Pandey, S.C. Comparative analysis of fungal and bacterial enzymes in biodegradation of xenobiotic compounds. Smart Bioremediation Technol. Microb. Enzym. 2019, 10, 169-189.

21. Bhatt, P.; Huang, Y.; Zhang, W.; Sharma, A.; Chen, S. Enhanced cypermethrin degradation kinetics and metabolic pathway in Bacillus thuringiensis strain SG4. Microorganims 2020, 8, 223. [CrossRef]

22. Chen, S.; Hu, Q.; Hu, M.; Luo, J.; Weng, Q.; Lai, K. Isolation and characterization of a fungus able to degrade pyrethroids and 3-phenoxybenzaldehyde. Bioresour. Technol. 2011, 102, 8110-8116. [CrossRef] [PubMed]

23. Birolli, W.G.; Alvarenga, N.; Seleghim, M.H.R.; Porto, A.L.M. Biodegradation of the pyrethroid pesticide esfenvalerate by marine-derived fungi. Mar. Biotechnol. 2016, 18, 511-520. [CrossRef] [PubMed]

24. Birolli, W.G.; Vacondio, B.; Alvarenga, N.; Seleghim, M.H.R.; Porto, A.L.M. Enantioselective biodegradation of the pyrethroid ( \pm )-lambda-cyhalothrin by marine-derived fungi. Chemosphere 2018, 197, 651-660. [CrossRef] [PubMed]

25. Palmer-Brown, W.; de Melo Souza, P.L.; Murphy, C.D. Cyhalothrin biodegradation in Cunninghamella elegans. Environ. Sci. Pollut. Res. 2018, 26, 1414-1421. [CrossRef] [PubMed]

26. Wu, P.C.; Liu, Y.H.; Wang, Z.Y.; Zhang, X.Y.; Li, H.; Liang, W.Q.; Luo, N.; Hu, J.M.; Lu, J.Q.; Luan, T.G.; et al. Molecular cloning, purification, and biochemical characterization of a novel pyrethroid-hydrolyzing esterase from Klebsiella sp. strain ZD112. J. Agric. Food Chem. 2006, 54, 836-842. [CrossRef] 
27. Chen, S.; Liu, C.; Peng, C.; Liu, H.; Hu, M.; Zhong, G. Biodegradation of chlorpyrifos and its hydrolysis product 3,5,6-trichloro-2-pyridinol by a new fungal strain Cladosporium cladosporioides Hu-01. PLoS ONE 2012, 7, e47205. [CrossRef]

28. Birolli, W.G.; Arai, M.S.; Nitschke, M.; Porto, A.L.M. The pyrethroid ( \pm )-lambda-cyhalothrin enantioselective biodegradation by a bacterial consortium. Pestic. Biochem. Physiol. 2019, 156, 129-137. [CrossRef]

29. Oliveira, B.R.; Penetra, A.; Cardoso, V.V.; Benoliel, M.J.; Crespo, M.T.V.; Samson, R.A.; Pereira, V.J. Biodegradation of pesticides using fungi species found in the aquatic environment. Environ. Sci. Poll. Res. 2015, 22, 11781-11791. [CrossRef]

30. Barh, A.; Kumari, B.; Sharma, S.; Annepu, S.K.; Kumar, A.; Kamal, S.; Sharma, V.P. Mushroom mycoremediation: Kinetics and mechanism. Smart Bioremediation Technol. Microb. Enzym. 2019, 1, $1-22$.

31. Zhao, J.; Jia, D.; Chi, Y.; Yao, K. Co-metabolic enzymes and pathways of 3-phenoxybenzoic acid degradation by Aspergillus oryzae M-4. Ecotoxicol. Environ. Saf. 2020, 189, 109953. [CrossRef]

32. Bhatt, P.; Bhatt, K.; Huang, Y.; Ziqiu, L.; Chen, S. Esterase is a powerful tool for the biodegradation of pyrethroid insecticides. Chemosphere 2020, 244, 125507. [CrossRef] [PubMed]

33. Cycoń, M.; Mrozik, A.; Piotrowska-Seget, Z. Bioaugmentation as a strategy for the remediation of pesticide-polluted soil: A review. Chemosphere 2017, 172, 52-71. [CrossRef] [PubMed]

34. Bhatt, P.; Huang, Y.; Rene, E.R.; Kumar, A.J.; Chen, S. Mechanism of allethrin biodegradation by a newly isolated Sphingomonas trueperi strain CW3 from wastewater sludge. Bioresour. Technol. 2020, 305, 123074. [CrossRef]

35. Chen, S.; Luo, J.; Hu, M.; Geng, P.; Zhang, Y. Microbial detoxification of bifenthrin by a novel yeast and its potential for contaminated soils treatment. PLoS ONE 2012, 7, e30862. [CrossRef] [PubMed]

36. Zhan, H.; Wang, H.; Liao, L.; Feng, Y.; Fan, X.; Zhang, L.; Chen, S. Kinetics and novel degradation pathway of permethrin in Acinetobacter baumannii ZH-14. Front. Microbiol. 2018, 9, 98. [CrossRef]

37. Gangola, S.; Sharma, A.; Bhatt, P.; Khati, P.; Chaudhary, P. Presence of esterase and laccase in Bacillus subtilis facilitates biodegradation and detoxification of cypermethrin. Sci. Rep. 2018, 8, 12755. [CrossRef]

38. Chen, S.; Yang, L.; Hu, M.; Liu, J. Biodegradation of fenvalerate and 3-phenoxybenzoic acid by a novel Stenotrophomonas sp. strain ZS-S-01 and its use in bioremediation of contaminated soils. Appl. Microbiol. Biotechnol. 2011, 90, 755-767. [CrossRef]

39. Chen, S.; Lai, K.; Li, Y.; Hu, M.; Zhang, Y.; Zeng, Y. Biodegradation of deltamethrin and its hydrolysis product 3-phenoxybenzaldehyde by a newly isolated Streptomyces aureus strain HP-S-01. Appl. Microbiol. Biotechnol. 2011, 90, 1471-1483. [CrossRef]

40. Chen, S.; Geng, P.; Xiao, Y.; Hu, M. Bioremediation of $\beta$-cypermethrin and 3-phenoxybenzaldehyde contaminated soils using Streptomyces aureus HP-S-01. Appl. Microbiol. Biotechnol. 2012, 94, 505-515. [CrossRef]

41. Chen, S.; Hu, M.; Liu, J.; Zhong, G.; Yang, L.; Rizwan-ul-Haq, M.; Han, H. Biodegradation of beta-cypermethrin and 3-phenoxybenzoic acid by a novel Ochrobactrum lupini DG-S-01. J. Hazard. Mater. 2011, 187, 433-440. [CrossRef]

42. Chen, S.; Chang, C.; Deng, Y.; An, S.; Dong, Y.H.; Zhou, J.; Hu, M.; Zhong, G.; Zhang, L.H. Fenpropathrin biodegradation pathway in Bacillus sp. DG-02 and its potential for bioremediation of pyrethroid-contaminated soils. J. Agric. Food Chem. 2014, 62, 2147-2157. [CrossRef] [PubMed]

43. Chen, S.; Deng, Y.; Chang, C.; Lee, J.; Cheng, Y.; Cui, Z.; Zhou, J.; He, F.; Hu, M.; Zhang, L.H. Pathway and kinetics of cyhalothrin biodegradation by Bacillus thuringiensis strain ZS-19. Sci. Rep. 2015, 5, 8784. [CrossRef]

44. Yoshida, T. Simultaneous determination of 18 pyrethroids in indoor air by gas chromatography/mass spectrometry. J. Chromatogr. A 2009, 1216, 5069-5076. [CrossRef] [PubMed]

45. Hu, W.; Xie, W.; Chen, S.; Zhang, N.; Zou, Y.; Dong, X.; Rashid, M.; Xiao, Y.; Hu, M.; Zhong, G. Separation of cis- and trans-cypermethrin by reversed-phase high-performance liquid chromatography. J. Chromatogr. Sci. 2015, 53, 612-618. [CrossRef]

46. Pankaj; Sharma, A.; Gangola, S.; Khati, P.; Kumar, G.; Srivastava, A. Novel pathway of cypermethrin biodegradation in a Bacillus sp. strain SG2 isolated from cypermethrin-contaminated agriculture field. 3 Biotech 2016, 6, 45. [CrossRef] [PubMed] 
47. Chen, S.; Dong, Y.H.; Chang, C.; Deng, Y.; Zhang, X.F.; Zhong, G.; Song, H.; Hu, M.; Zhang, L.H. Characterization of a novel cyfluthrin-degrading bacterial strain Brevibacterium aureum and its biochemical degradation pathway. Bioresour. Technol. 2013, 132, 16-23. [CrossRef]

48. Cycoń, M.; Zmijowska, A.; Piotrowska-Seget, Z. Enhancement of deltamethrin degradation by soil bioaugmentation with two different strains of Serratia marcescens. Int. Environ. Sci. Technol. 2014, 11, 1305-1316. [CrossRef]

49. Zhan, H.; Feng, Y.; Fan, X.; Chen, S. Recent advances in glyphosate biodegradation. Appl. Microbiol. Biotechnol. 2018, 10, 5033-5043. [CrossRef]

50. Huang, Y.; Zhan, H.; Bhatt, P.; Chen, S. Paraquat degradation from contaminated environments: Current achievements and perspectives. Front. Microbiol. 2019, 10, 1754. [CrossRef]

51. Tang, A.X.; Liu, H.; Liu, Y.Y.; Li, Q.Y.; Qing, Y.M. Purification and characterization of a novel $\beta$-cypermethrin-degrading aminopeptidase from Pseudomonas aeruginosa GF31. J. Agric. Food Chem. 2017, 65, 9412-9418. [CrossRef]

52. Feng, Y.; Huang, Y.; Zhan, H.; Bhatt, P.; Chen, S. An overview of strobilurin fungicide degradation: Current status and future perspective. Front. Microbiol. 2020, 11, 389. [CrossRef] [PubMed]

53. Zhang, W.; Lin, Z.; Pang, S.; Bhatt, P.; Chen, S. Insights into the biodegradation of lindane ( $\gamma$-hexachlorocyclohexane) using a microbial system. Front. Microbiol. 2020, 11, 522. [CrossRef]

54. Lin, Z.; Zhang, W.; Pang, S.; Huang, Y.; Mishra, S.; Bhatt, P.; Chen, S. Current approaches to and future perspectives on methomyl degradation in contaminated soil/water environments. Molecules 2020, $25,738$. [CrossRef] [PubMed]

55. Hu, K.; Deng, W.; Zhu, Y.; Yao, K.; Li, J.; Liu, A.; Ao, X.; Zou, L.; Zhou, K.; He, L.; et al. Simultaneous degradation of $\beta$-cypermethrin and 3-phenoxybenzoic acid by Eurotium cristatum ET1, a novel“golden flower fungus" strain isolated from Fu Brick Tea. Microbiol. Open 2018, 8, 7. [CrossRef] [PubMed]

56. Harms, H.; Schlosser, D.; Wick, L.Y. Untapped potential: Exploiting fungi in bioremediation of hazardous chemicals. Nat. Rev. Microbiol. 2011, 9, 177-192. [CrossRef]

57. Deng, W.Q.; Lin, D.R.; Yao, K.; Yuan, H.Y.; Wang, Z.L.; Li, J.L.; Zou, L.K.; Han, X.F.; Zhou, K.; He, L.; et al. Characterization of a novel beta-cypermethrin-degrading Aspergillus niger YAT strain and the biochemical degradation pathway of beta-cypermethrin. Appl. Microbiol. Biotechnol. 2015, 99, 8187-8198. [CrossRef]

58. Yu, Y.L.; Fang, H.; Wang, X.; Wu, X.M.; Shan, M. Characteristics of fungal a fungal strain capable of degrading chlorpyrifos and its use in detoxification of the insecticide on vegetables. Biodegradation 2011, 17, 487-494. [CrossRef]

59. Chen, S.; Lin, Q.; Xiao, Y.; Deng, Y.; Chang, C.; Zhong, G.; Hu, M.; Zhang, L.H. Monooxygenase, a novel beta-cypermethrin degrading enzyme from Streptomyces sp. PLoS ONE 2013, 8, e75450. [CrossRef]

60. Wang, T.; Hu, C.; Zhang, R.; Sun, A.; Li, D.; Shi, X. Mechanism study of cyfluthirn biodegradation by Photobacterium ganghwense with comparative metabolomics. Appl. Microbiol. Biotechnol. 2018, 103, 473-488. [CrossRef] [PubMed]

61. Xiao, Y.; Chen, S.H.; Gao, Y.Q.; Hu, W.; Hu, M.Y.; Zhong, G.H. Isolation of a novel beta-cypermethrin degrading strain Bacillus subtilis BSF01 and its biodegradation pathway. Appl. Microbiol. Biotechnol. 2015, 99, 2849-2859. [CrossRef] [PubMed]

62. Chen, S.; Luo, J.J.; Hu, M.Y.; Lai, K.P.; Geng, P.; Huang, H.S. Enhancement of cypermethrin degradation by a coculture of Bacillus cereus ZH-3 and Streptomyces aureus HP-S-01. Bioresour. Technol. 2012, 110, 97-104. [CrossRef] [PubMed]

63. Zhang, C.; Wang, S.H.; Yan, Y.C. Isomerization and biodegradation of beta-cypermethrin by Pseudomonas aeruginosa CH7 with biosurfactant production. Bioresour. Technol. 2011, 102, 7139-7146. [CrossRef] [PubMed]

64. Pang, S.; Lin, Z.; Zhang, W.; Mishra, S.; Bhatt, P.; Chen, S. Insights into the microbial degradation and biochemical mechanisms of neonicotinoids. Front. Microbiol. 2020, 11, 868.

65. Guo, P.; Wang, B.; Hang, B.J.; Li, L.; Ali, S.W.; He, J.; Li, S. Pyrethroid-degrading Sphingobium sp. JZ-2 and the purification and characterization of a novel pyrethroid hydrolase. Int. Biodeterior. Biodegradation 2009, 63, 1107-1112. [CrossRef]

66. Wang, B.; Guo, P.; Hang, B.; Li, L.; He, J.; Li, S.P. Cloning of a novel pyrethroid-hydrolyzing carboxylesterase gene from Sphingobium sp. strain JZ-1. Appl. Environ. Microbiol. 2009, 75, 5496-5500. [CrossRef] [PubMed] 
67. Lin, Q.; Chen, S.; Hu, M.; Rizwan-ul-Haq, M.; Yang, L.; Li, H. Biodegradation of cypermethrin by a newly isolated actinomycetes HU-S-01 from wastewater sludge. Int. J. Environ. Sci. Technol. 2011, 8, 45-56. [CrossRef]

68. Zhai, Y.; Li, K.; Song, J.; Shi, Y.; Yan, Y. Molecular cloning, purification and biochemical characterization of a novel pyrethroid-hydrolyzing carboxylesterase gene from Ochrobactrum anthropi YZ-1. J. Hazard. Mater. 2012, 221-222, 206-212. [CrossRef]

69. Jilani, S.; Khan, M.A. Biodegradation of cypermethrin by Pseudomonas in a batch activated sludge process. Int. J. Environ. Sci. Technol. 2006, 3, 371-380. [CrossRef]

(C) 2020 by the authors. Licensee MDPI, Basel, Switzerland. This article is an open access article distributed under the terms and conditions of the Creative Commons Attribution (CC BY) license (http://creativecommons.org/licenses/by/4.0/). 